\title{
INHIBITION OF EUKARYOTIC CELLFREE PROTEIN SYNTHESIS BY THIONINS FROM WHEAT ENDOSPERM
}

\author{
FRANCISCO GARCIA-OLMEDO, PILAR CARBONERO, CARLOS HERNANDEZ-LUCAS, JAVIER PAZ-ARES, \\ FERNANDO PONZ, OSCAR VICENTE " and JOSE M. SIERRA ${ }^{3}$
}

Departamento de Bioquimica, E.T.S. Ingenieros Agrónomos, Universidad Politécnica, Madrid.3, and ${ }^{\circ}$ Centro de Biologia Molecular, Universidad Auónoma, Madrid-34 (Spain)

Key words: Protein synthesis; Thionin inhibition; Plant toxin; (Wheat endosperm)

Thionins are polypeptide toxins of about $\mathbf{5 0 0 0}$ molecular weight, present in the endosperms of many Gramineae, which modify membrane permeability and inhibit macromolecular synthesis in cultured mammalian cells. Evidence is presented that they inhibit in vitro protein synthesis at micromolar concentrations in cell-free systems derived from wheat germ or from rabbit reticulocytes. Inhibition seems to occur by direct binding of mRNA by the toxin, as judged by the ability of thionins to mediate retention of RNA in nitrocellulose filters and by the dependence of inhibitory concentrations on the amount of exogenous RNA added to the wheat-germ translation system. Commercial preparations of wheat-germ have been found to include some endosperm contamination (up to 15\%), which may result in at least partially inhibitory concentrations of the toxin in the cell-free extracts.

\section{Introduction}

The thionins are cystine-rich polypeptide toxins (4 -S-S- 45 amino acids) present in the endosperms of many Gramineae, including wheat [1-5]. They have more than half of their amino acid sequence in common with the cardiotoxic viscotoxins ( 3 -S-S- $/ 46$ anino acids), isolated from the mistletoes [6-7], and about 30\% homology with the non-toxic crambin ( 3 -S-S- $/ 46$ amino acids), purified from Crambe abyssinica [8]. We have recently shown that both thionins and viscotoxins modify membrane permeability in cultured mammalian cells, inducing leakiness to low-molecularweight compounds and ions [9]. It was also observed that they inhibit in vivo macromolecular synthesis. Protein synthesis, which was more sensitive than RNA or DNA synthesis, was inhibited at the same concentrations required to induce leakage. which suggested that the inhibition could be a consequence of the alteration of the ionic composition of the cytoplasm, although a more direct effect on specific steps of the process could not be excluded [9]. We report here that thionins inhibit in vitro protein synthesis both in the wheat germ and in the rabbit reticulocyte lysate systems, probably by direct binding of mRNA. We also show that commercial wheat-germ samples, which have variable amounts of contaminant endosperm, may have enough thionins to inhibit the in vitro system.

\section{Materials and Methods}

Thionins. Wheat thionins (purothionins) were obtained from Triticum aestivum L cv. Aragón 03. Endosperm was extracted with petroleum ether 
and the extract was concentrated in vacuo. Thionins $\left(\alpha_{1}, \alpha_{2}\right.$ and $\beta$ ) were precipitated with 3 vol. $1 \mathrm{M} \mathrm{HCl}$ in ethanol and purified by preparative electrophoresis as previously described [9].

Monospecific antibodies and radial immunodiffusion. Thionins were coupled to bovine serum albumin and injected into rabbits essentially as described [10]. Serum was precipitated with $25 \%$ $\left(\mathrm{NH}_{4}\right)_{2} \mathrm{SO}_{4}$ and monospecific antibodies were obtained by affinity chromatography according to Shapiro et al. [1]]. Quantitation of thionins in wheat germ was carried out by radial immunodiffusion [12], using purified thionins as standards.

Preparation of poly $(A)^{+}$RNA from barley endosperm. Developing barley endosperm was extruded into liquid nitrogen at about 20 days after anthesis. Polysomal RNA was prepared according to Larkins et al. [13] and poly(A) ${ }^{+}$mRNA was obtained by affinity chromatography on oligo(dT) cellulose (type 7, P-L Biochemicals) [14].

Wheat-germ translation system. Embryos from Triticum turgidum cv. Ledesma were obtained by hand-dissection and used to prepare S-23 fractions essentially as described by Roberts and Patterson [15], except that 2.5 volumes of buffer were used for the extraction step. Wheat germs from General Mills (U.S.A.), Niblack (U.S.A.), Marriages Ltd. (U.K., a gift from B.J. Miflin) and Fysis (Spain) were also used to obtain the corresponding $\mathrm{S}-23$ fractions in the same manner. Standard protein synthesis assays contained the following components in $25 \mu \mathrm{l}: 70 \mathrm{mM}$ potassium acetate, $2.5 \mathrm{mM}$ magnesium acetate, $100 \mu \mathrm{M}$ spermine, $20 \mathrm{mM}$ Hepes (pH 7.6), $1 \mathrm{mM}$ dithiothreitol, $1 \mathrm{mM}$ ATP, $30 \mu \mathrm{M}$ GTP, $10 \mathrm{mM}$ creatine phosphate, $40 \mu \mathrm{g} / \mathrm{ml}$ creatine kinase, $20 \mu \mathrm{M}$ non-radioactive amino acids, $200 \mu \mathrm{Ci} / \mathrm{ml}$ of $\left[{ }^{35} \mathrm{~S}\right]$ methionine $(780 \mathrm{Ci} / \mathrm{m}$ mol, New England Nuclear), $10 \mu l$ of wheat embryo S-23. Total RNA, or poly(A) ${ }^{+}$RNA, and thionins were added as indicated in each case. Poly(U) was translated without spermine in 100 $\mathrm{mM}$ potassium acetate and $9 \mathrm{mM}$ magnesium acetate, using $\left[{ }^{3} \mathrm{H}\right]$ phenylalanine $(15 \mathrm{Ci} / \mathrm{mmol}$, New England Nuclear). Incubations were carried out at $28^{\circ} \mathrm{C}$ and the radioactivity incorporated into protein was determined in $3-\mu$ l aliquots.

Reticulocyte lysate translation system. Reticulocyte lysates from phenylhydrazine-treated rabbits were prepared essentially as described by Hunt and Jackson [16]. Standard protein synthesis assays contained the following components in $30 \mu$ ]: $80 \mathrm{mM} \mathrm{KCl}, 0.3 \mathrm{mM} \mathrm{MgCl}_{2}, 10 \mathrm{mM}$ creatine phosphate, $1 \mu \mathrm{g}(0.1$ unit) of creatine kinase, $1.5 \mu 1$ of a mixture of 19 non-radioactive amino acids at concentrations related to their frequency of occurrence in rabbit globin [16], $0.05 \mathrm{mM} \mathrm{L}-\left[{ }^{14} \mathrm{C}\right]$ leucine $(144 \mathrm{mCi} / \mathrm{mmol}), 19 \mu$ l of reticulocyte lysate, thionins at the indicated concentrations, and, when present, $16 \mu \mathrm{M}$ hemin. Incubation was at $30^{\circ} \mathrm{C}$ and the radioactivity incorporated into protein was determined in 3- $\mu$ l aliquots.

RNA binding assay. Assay samples $(25 \mu \mathrm{l})$ contained $20 \mathrm{mM}$ Hepes (pH 7.6) $100 \mathrm{mM} \mathrm{KCl,}$ $\mathrm{mM}$ magnesium acetate, $1 \mathrm{mM}$ dithiothreitol, labelled RNA and thionins as indicated in the legends. After incubation for $5 \mathrm{~min}$ at $30^{\circ} \mathrm{C}$, the reaction was stopped by dilution with $2 \mathrm{ml}$ of cold wash buffer (20 mM Tris- $\mathrm{HCl}(\mathrm{pH} 7.6), 100 \mathrm{mM}$ $\mathrm{KCl}, 1 \mathrm{mM}$ magnesium acetate, $1 \mathrm{mM}$ dithiothreitol) and the samples were filtered through nitrocellulose membranes (Millipore Hawpo 2500, $0.45 \mu \mathrm{m}$ pore size). The filters were washed twice with $3 \mathrm{ml}$ of the above buffer, dried, and the retained radioactivity was measured. Foot and mouth disease virus poly $(\mathrm{A}){ }^{+}\left[{ }^{32} \mathrm{P}\right] \mathrm{RNA}$ was the gift of $J$. Ortin and $E$. Domingo and $\left[{ }^{3} \mathrm{H}\right] \mathrm{Met}-$ tRNA $A_{i}$ was prepared according to Stanley [17], using crude tRNA from calf liver (Boehringer).

\section{Results}

Thionins were found to inhibit eukaryotic protein synthesis. Both the mRNA-dependent wheatgerm system and the rabbit reticulocyte lysate endogenous translation system were about equally inhibited by toxin concentrations in the $\mu M$ range (Fig. $1 A$ and $B$ ).

Further inhibition tests with the wheat-germ system, using poly $(\mathrm{A})^{+}$RNA and total polysomal RNA from barley endosperm, as well as poly(U), indicated that toxin concentrations giving $50 \%$ inhibition ( $\mathrm{ID}_{50}$ ) increased with the exogenous RNA concentrations (Fig. 2), which suggested a direct binding of the RNA by the toxin. To test further this hypothesis, toxin-mediated retention of radioactively labelled RNA by nitrocellulose filters was investigated. Both poly $(A){ }^{+}\left[{ }^{32}\right.$ P]RNA from the foot and mouth disease virus and $\left[{ }^{3} \mathrm{H}\right] \mathrm{Met}-\mathrm{tRNA}$; 


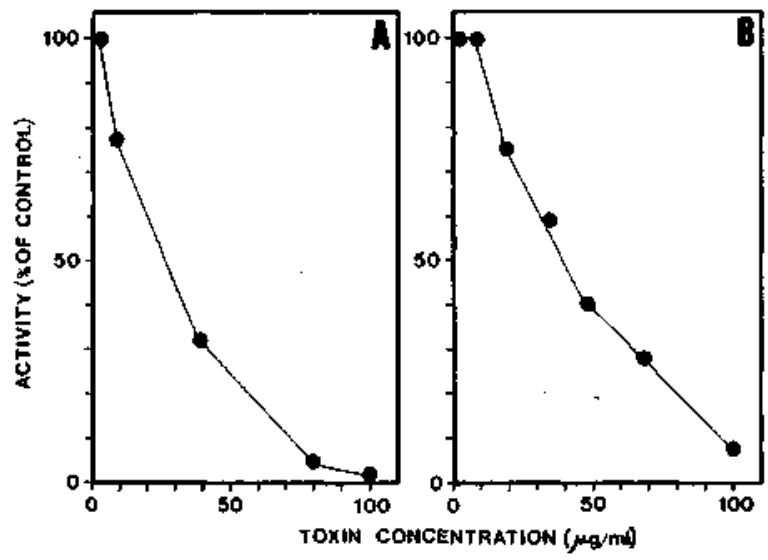

Fig. l. Inhibition of eukaryotic cell-free prolein synthesis by thionins. (A) Wheal-embryo system ( $T$. turgidum, cy. Ledesma): assays are described in Materials and Methods; $20 \mu \mathrm{g} / \mathrm{ml}$ of poly $(A)^{+}$RNA from barley endosperm were used in all tubes; thionin concentration of $5 \mu \mathrm{g} / \mathrm{ml}=1 \mu \mathrm{M} ; 100 \%$ activity was $31600 \mathrm{cpm} / 3 \mu \mathrm{l}$ over an endogenous activity of $2500 \mathrm{cpm} / 3$ $\mu \mathrm{l}$, using $\left[{ }^{35} \mathrm{~S}\right]$ methionine; $45 \mathrm{~min}$ incubation. (B) Rabbit reticulocyte lysate; assays are described in Materials and Methods; $100 \%$ activity was $21174 \mathrm{cpm} / 3 \mu \mathrm{l}$, which is the difference of $\left[{ }^{14} \mathrm{C}\right]$ leucine incorporated in the presence of hemin $(29273$ $\mathrm{cpm} / 3 \mu \mathrm{l})$ and in its absence $(8099 \mathrm{cpm} / 3 \mu \mathrm{l}) ; 30 \mathrm{~min}$ incubation.

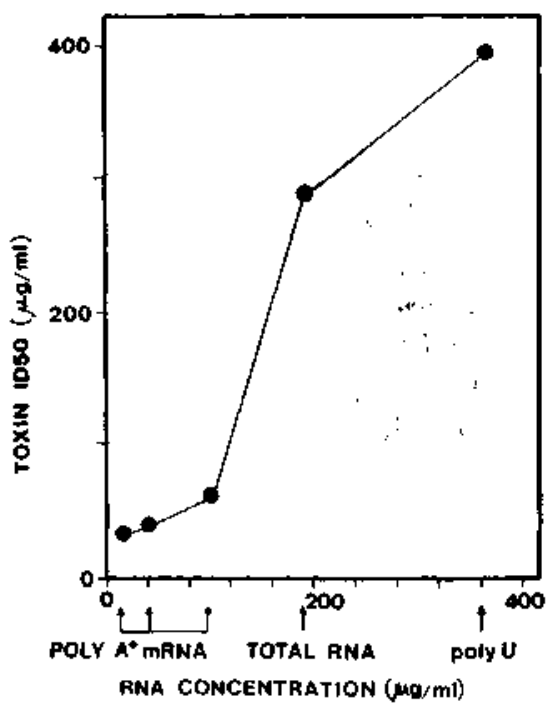

Fig. 2. Dependence of the toxin concentration required for $50 \%$ inhibition of translation on the amount of RNA added to the wheat-embryo system (Ledesma wheat). Poly(A) ${ }^{+}$RNA and total polysomal RNA were from barley endosperm. Conditions are described in Materials and Methods.

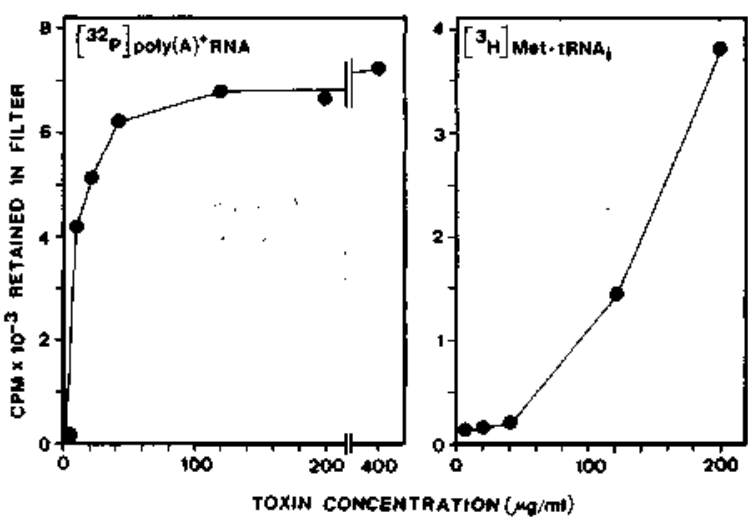

Fig. 3. Binding of labelled RNA by thionins. Foot and mouth disease virus poly $(A)^{+}\left[{ }^{32}\right.$ P]RNA $\left(10^{6} \mathrm{cpm} / \mu \mathrm{g}\right), 7300 \mathrm{cpm} /$ sample. $\left[{ }^{3} \mathrm{H}\right] M e t-1 R N A_{i}, 27800 \mathrm{cpm} /$ sample. $9.6 \mu \mathrm{g} /$ sample of total tRNA (about $0.045 \mu \mathrm{g}$ of labelled tRNA). Bovine serum albumin did not show any binding to both RNAs at the same concentrations as thionins.

were retained by the filters in the presence of micromolar concentrations of the toxin (Fig. 3A and $B$ ). In the second case, the apparent efficiency of retention was lower than in the first because of the lower overall specific activity of the RNA in the sample, which included a high proportion of unlabelled tRNA species. The extent of binding of thionins to $\left[{ }^{3} \mathrm{H}\right] \mathrm{Met}-\mathrm{RNA} \mathrm{A}_{i}$, which was not increased by GTP, was very similar to the GTP-dependent binding of initiation factor $\mathrm{eIF}_{2}$ from rabbit reticulocytes to the same $\left[\mathrm{H}^{3}\right] \mathrm{Met}-\mathrm{RNA}$; preparation (data not shown). The binding of thionin to this tRNA does not seem to be specific. as $\left[{ }^{3} \mathbf{H}\right]$ Phe-tRNA from yeast was also retained in the filter (data not shown).

Commercial samples of wheat germ have variable amounts of contaminating endosperm, especially if they have been obtained from non-vitreous kernels, so it was considered of interest to determine their toxin contents, in view of their widespread use in preparing the mRNA-dependent in vitro translation system. Quantitation was carried out by radial immunodiffusion (Table I). Thionin was not detected in hand-dissected embryos and was present in different wheat endosperms at concentrations in the $1000-2000 \mu \mathrm{g} / \mathrm{g}$ range. Concentrations in the wheat germs were $70-160 \mu \mathrm{g} / \mathrm{g}$, indicating a contamination by endosperm of up to $15 \%$ (Table I). Wheat-germ extracts 
TABLE 1

THIONIN CONTENTS AND TRANSLATIONAL EFFICIENCIES OF COMMERCIAL WHEAT GERMS

Thionin contents were determined by radial immunodiffusion and translation efficiencies by comparison with hand-dissected embryos from Ledesma wheat $(100 \%=26000 \mathrm{cpm} / 3 \mu \mathrm{l}$ above endogenous activity; the concentration of mRNA used (0.5 $\mu \mathrm{g} / 25 \mu \mathrm{l}$ ) was well below the saturation concentration (approx. $2 \mu \mathrm{g} / 25 \mu())$.

\begin{tabular}{llc}
\hline Sample & $\begin{array}{l}\text { Thionins } \\
(\mu \mathrm{g} / \mathrm{g})\end{array}$ & $\begin{array}{l}\text { Protein synthesis } \\
\text { (\% of Ledesma) }\end{array}$ \\
\hline Wheal endosperms & $1000-2000$ & - \\
Ledesma embryo & 0 & 100 \\
General Mills & 70 & 138 \\
Niblack & 80 & 80 \\
Marriage Ltd. & 120 & 65 \\
Fysis & 160 & 0 \\
\hline
\end{tabular}

were prepared from the same samples and their ability to mediate protein synthesis was compared (Table I).

\section{Discussion}

Proteins capable of inhibiting eukaryotic cellfree translation have been found in seeds and other parts of many plant species [18]. The most thoroughly studied type of inhibitor is represented by toxins, such as ricin and abrin, that consist of an $\mathbf{A}$ (active) chain and $\mathbf{a} \mathrm{B}$ (binding) chain, both of which are required for toxicity to intact mammalian cells, while the $A$ chain alone is able to inhibit cell-free translation [19]. A more numerous group of inhibitors consists of single, A-chain-like non-toxic proteins $[20,21]$. A-chains act by catalytic inactivation of ribosomes and are much more active on animal than on plant systems [19-23]. Tritin, a single-chain non-toxic inhibitor isolated from wheat seeds, is a basic protein of about 30000 molecular weight which seems to be inactive against the homologous cell-free system [23]. Other types of plant inhibitors that have been described include wheat-germ agglutinin (WGA), which seems to inhibit by reversibly binding to ribosomes through disulphide interchange [24], and an inhibitor from wheat germ (WGI) that phosphorylates initiation factor $\mathrm{eIF}_{2}[25]$.
Thionins differ from the above inhibitors in that they are single polypeptides which are active both against whole cells and against cell-free systems. Inhibition of protein synthesis seems to occur by direct binding of mRNA to the toxin, as $\mu \mathrm{M}$ concentrations of thionin mediate retention of RNA by nitrocellulose filters and inhibitory concentrations depend on the amounts of exogenous RNA added. This mechanism is further supported by the fact that the toxin is inactivated by modification of its lysine amino groups [26].

The $I_{50}$ values of thionins against both eucariotic systems tested are of the same order as those described for WGA [24] and WGI [25]. The A-chains of ricin and Ricinus communis agglutinin show inhibitory activity against plant systems similar to that of thionins, but are considerably more active (over 100-fold) against animal systems $[19,20,22]$.

Thionins are quite abundant in cereal endosperm, where they are synthesized as larger precursors which are processed in two steps and deposited in the endoplasmic reticulum (unpublished data). Their absence from the cytosol probably precludes their interference with in vivo protein synthesis. On the other hand, thionins re readily exiractable from dry, mature endosperm by buffers with moderate salt concentrations, such as that used for in vitro translation. Thus, under the standard conditions used, toxin concentrations in the final translation mixture can be as high as 25 $\mu \mathrm{g} / \mathrm{ml}$, well within the inhibitory concentration range. No strict correlation between thionin content of different wheat-germ extracts and their ability to mediate protein synthesis was to be expected, because of the probable variation of other factors, but the wheat-germs with higher toxin content yielded the extracts with the lower translation efficiency.

The physiological functions of thionins are as yet unknown, although they could have the role of protecting the starchy endosperm against infection during development and germination $[9,23,27]$.

\section{Acknowledgements}

This work was supported by grants from the Fundación Ramón Areces and from the Comision Asesora de Investigación Científica y Técnica. 


\section{References}

1 Balls, A.K. and Hale, W.S. (1942) Cereal Chem. 19, 279-288

2 Carbonero, P. and Garcia-Olmedo, F. (1969) Experientia (Basel) 25, 1110

3 Redman, G.D. and Fisher, N. (1969) J. Sci. Food Agric. 20, 427-432

4 Fernández de Caleya, R., Hernández-Lucas, C., Carbonero, P. and Garcia-Olmedo, F. (1976) Genetics 83, 687-699

5 Hernandez-Lucas, C., Carbonero, P. and Garcia-Olmedo, F. (1978) J. Agric. Food Chem. 26, 794-796

6 Jones, B.L. and Mak, A.S. (1977) Cereal Chem. S4, 511-523

7 Samuelsson, G. (1973) Syst. Zool. 22, 566-570

8 Teeter, M.M., Mazer, J.A. and L'Italien, J.J. (198I) Biochemistry $20,5437-5443$

9 Carrasco, L., Vazquez, D., Hernández-Lucas, C., Carbonero, P. and Garcia-Olmedo, F. (1981) Eur. J. Biochem. 116, 185-189

I0 Tai, H.H. and Chey, W.Y. (1978) Anal. Biochem. 87, 350-358

I1 Shapiro, D.J., Taylor, J.M., Mcknight, G.S., Palacios, R., González, C., Kiely, M.L. and Schimke, R.T. (1974) J. Biol. Chem. 249, 3665-3671

12 Garvey, J.S., Cremer, N.E. and Sussdorf, D.H. (1977) Methods in Immunology, W.A. Benjamin Inc., Reading, MA

13 Larkins, B.A., Jones, R.A. and Tsai, C.Y. (1976) Biochemistry $15,5506-5511$
14 Aviv, H. and Leder, P. (1972) Proc. Natl. Acad. Sci. U.S.A. $69,1408-1412$

15 Roberts, B.E. and Patterson. B.M. (1973) Proc. Natl. Acad. Sci. U.S.A. 70, 2330-2334

16 Hunt, T. and Jackson. R.J. (1974) in Modern Trends in Human Leukemia (Neth. R., ed.), pp. 300, 307, J.F. Lehmans Verlag, Munich

17 Stanley, W.M., Jr. (1974) Methods Enzymol. 29E, 530-547

18 Gasperi-Campani, A., Barbieri, L., Morelli, P. and Stirpe, F. (1980) Biochem. J. 186, 439-441

19 Otsnes, S. and Pihl, A. (1977) in Receptors and Recognition, Series B. Vol. I (Cuatrecasas. P., ed.). pp. 129-172. Chapman and Hall, London

20 Stirpe, F., Olsnes, S. and Pihl, A. (1980) J. Biol, Chern. 255. 6947-6953

21 Irvin, J.D. (1975) Arch. Biochem. Biophys. 169, 522-528

22 Harley, S.M. and Beevers, H. (1982) Proc. Natl. Acad. Sci. U.S.A. 75, 5935-5938

23 Coleman, W.H. and Roberts, W.K. (1982) Biochim. Biophys. Acta 696, 239-244

24 Abraham, A.K., Kolseth, S. and Pihl, A. (1982) Eur. J. Biochem. 124, 383-388

25 Ranu, R.S. (1980) Biochem. Biophys. Res. Commun. 97. 1124-1132

26 Wada, K., Ozaki, Y., Matsubara, H. and Yoshizumi. H. (1982) J. Biochem. (Tokyo) 91, 257-263

27 Fernández de Calieya, R., Gonzälez-Pascual. B.. GarciaOlmedo, F. and Carbonero. P. (1972) Appl. Microbiol, 23. $998-1000$ 